\title{
Aura-biomes are present in the water layer above coral reef benthic macro-organisms
}

\author{
Kevin Walsh ${ }^{\text {Corresp., }}{ }^{1}$, John Haggerty ${ }^{1}$, Michael P Doane ${ }^{1}$, John J Hansen ${ }^{1}$, Megan M Morris ${ }^{1}$, Ana Paula B \\ Moreira $^{2}{ }^{\text {, }}$ Louisi de Oliveira ${ }^{3}$, Luciana Leomil $^{3}{ }^{3}$, Gizele D Garcia ${ }^{4,5}$, Fabiano Thompson ${ }^{3}$, Elizabeth Dinsdale \\ 1 Department of Biology, San Diego State University, San Diego, California, United States \\ 2 Instituto de Biologia, Universidade Federal do Rio de Janeiro, Rio de Janeiro, Brazil \\ 3 Instituto de Biologia, Universidade Federal do Rio de Janeiro, Rio de Janeiro, Rio de Janeiro, Brazil \\ 4 Macae campus, Federal University of Rio de Janeiro, Macae, Rio de Janeiro, Brazil \\ 5 Laboratory of Microbiology, Institute of Biology, Federal University of Rio de Janeiro (UFRJ), Rio de Janeiro, Brazil \\ Corresponding Author: Kevin Walsh \\ Email address: kwalsh627@aol.com
}

As coral reef habitats decline worldwide, some reefs are transitioning from coral- to algaldominated benthos with the exact cause for this shift remaining elusive. Increases in the abundance of microbes in the water column has been correlated with an increase in coral disease and reduction in coral cover. Here we investigated how multiple reef organisms influence microbial communities in the surrounding water column. Our study consisted of a field assessment of microbial communities above replicate patches dominated by a single macro-organism. Metagenomes were constructed from $20 \mathrm{~L}$ of water above distinct macroorganisms, including 1) the coral Mussismilia braziliensis, 2) fleshy macroalgae (Stypopodium, Dictota and Canistrocarpus), 3) turf algae, and 4) the zoanthid Palythoa caribaeorum and were compared to the water microbes collected $3 \mathrm{~m}$ above the reef. Microbial genera and functional potential were annotated using MG-RAST and showed that the dominant benthic macro-organisms influence the taxa and functions of microbes in the water column surrounding them, developing a specific "aura-biome". The coral aura-biome reflected the open water column, and was associated with Synechococcus and functions suggesting oligotrophic growth, while the fleshy macroalgae aura-biome was associated with Ruegeria, Pseudomonas, and microbial functions suggesting low oxygen conditions. The turf algae aura-biome was associated with Vibrio, Flavobacterium, and functions suggesting pathogenic activity, while zoanthids were associated with Alteromonas and functions suggesting a stressful environment. Because each benthic organism has a distinct aura-biome, a change in benthic cover will change the microbial community of the water, which may lead to either the stimulation or suppression of the recruitment of benthic organisms. 
1 Aura-biomes are present in the water layer above coral reef benthic macro-organisms

2

3

Walsh, K. ${ }^{1}$, Haggerty, J. M. ${ }^{1}$, Doane, M. ${ }^{1}$, Hansen, J. ${ }^{1}$, Morris, M. ${ }^{1}$, Moreira, AP. ${ }^{2}$, de Oliveira, L. ${ }^{2}$, Leomil, L. ${ }^{2}$, Garcia, G. ${ }^{2,3}$, Thompson, F.L. ${ }^{2}$, Dinsdale, E.A. ${ }^{1}$

1. Department of Biology, San Diego State University, San Diego, CA 92182, USA 2. Institute of Biology, Lab of Microbiology and SAGE-COPPE, Federal University of Rio de Janeiro, RJ 21941-901, Brazil 3. Institute of Biology, Federal University of Rio de Janeiro Macaé Campus, Macaé, RJ 27930560, Brazil.

\section{Abstract}

As coral reef habitats decline worldwide, some reefs are transitioning from coral- to algal-dominated benthos with the exact cause for this shift remaining elusive. Increases in the abundance of microbes in the water column has been correlated with an increase in coral disease and reduction in coral cover. Here we investigated how multiple reef organisms influence microbial communities in the surrounding water column. Our study consisted of a field assessment of microbial communities above replicate patches dominated by a single macro-organism. Metagenomes were constructed from $20 \mathrm{~L}$ of water above distinct macro-organisms, including 1) the coral Mussismilia braziliensis, 2) fleshy macroalgae (Stypopodium, Dictota and Canistrocarpus), 3) turf algae, and 4) the zoanthid Palythoa caribaeorum and were compared to the water microbes collected $3 \mathrm{~m}$ above the reef. Microbial genera and functional potential were annotated using MG-RAST and showed that the dominant benthic macro-organisms influence the taxa and functions of microbes in the water column surrounding them, developing a specific "aura-biome". The coral aura-biome reflected the open water column, and was associated with Synechococcus and functions suggesting oligotrophic growth, while the fleshy macroalgae aura-biome was associated with Ruegeria, Pseudomonas, and microbial functions suggesting low oxygen conditions. The turf algae aurabiome was associated with Vibrio, Flavobacterium, and functions suggesting pathogenic activity, while zoanthids were associated with Alteromonas and functions suggesting a stressful environment. Because each benthic organism has a distinct aura-biome, a change in benthic cover will change the microbial community of the water, which may lead to either the stimulation or suppression of the recruitment of benthic organisms.

\section{Introduction}


35 Coral reef ecosystems are diverse but declining habitats (Jackson and Buss 1975; Hixon and Beets 1993;

36 Cantera et al., 2003; Hughes et al., 2010). Causes of coral cover decline are associated with overfishing,

37 disease, increased nutrients, water runoff, and increased water temperatures (Roberts and Nicholas 1993;

38 Hughes 1994, Weil et al., 2006; Hoegh-Guldberg et al., 2007; Hughes et al., 2007; De'ath et al. 2009).

39 Microbial communities are also integral in coral reef health and stability. Microbes associated with the

40 water of pristine coral reefs show a mix of autotrophs and heterotrophs, while the water of degraded reefs

41 is dominated by microbial heterotrophs including many pathogenic strains (Dinsdale et al., 2008a;

42 Morrow et al., 2012). The increase of pathogenic microbes in the reef water column is correlated with an

43 increase in the amount of coral disease (Dinsdale et al., 2008a). There are several hypotheses explaining

44 the increase of pathogens on coral reefs; the first is that microbes are transported from agricultural and

45 human sewage runoff into the ocean, and the second is that the microbial changes are being generated on

46 the reef (Dinsdale and Rohwer, 2011).

47

48 Early investigations of microbial associations with corals showed a strong relationship between the host macro-organism and their bacterial symbionts. Rohwer et al. (2002) showed that microbial communities of coral are host-specific, with the same species of coral sharing microbial communities over space and time compared with a different species that occupies an adjacent location on the same reef. The combination of the coral macro-organism, its symbiotic zooxanthellae and the associated microbial communities was termed the holobiont. This concept has been expanded to various reef macro-organisms including multiple species of macroalgae (Harder et al., 2012; Egan et al., 2013) and zoanthids (Sun et al., 2014), in addition to terrestrial organisms including plants and insects (Mandrioli and Manicardi 2013; Minard et al., 2013; Vandenkoornhuyse et al., 2015). Besides retaining a distinct microbial community on their surface, reef benthic organisms may influence microbes in the surrounding water environment. This can happen in two ways, 1) by the host-specific microbes being released or shed from the host into the surrounding water, and 2) the production of dissolved organic matter by the host, which stimulates the activity of a specific set of microbes within the boundary water layer.

Benthic organisms, like any submerged object, cause a variation in water flow across their surface, creating sheer forces and boundary layers (Shashar et al., 1996). Three boundary layers, the benthic (BBL), momentum (MBL), and diffusive (DBL; the closest to the benthic organism surface) (Barott and Rohwer 2013), act at different scales and will be influenced by the underlying benthos and the surrounding water to varying degrees. The flow speed of water across benthic surfaces will alter the thickness of the layers and affect the chemical and biological makeup of each parcel of water. High flow rates across a reef may homogenize the compounds in the benthic boundary layer; however, the water in 
69 the diffusive boundary layer may be stagnant and concentrate chemicals and the responding microbes.

70 Reef macro-organisms exude a range of chemicals into the boundary layers, altering the biogeochemical

71 nature of the water and the microbial metabolisms that occur in the layers (Haas et al., 2011). Benthic

72 organisms on a coral reef, such as coral, algae, and crustose coralline algae, influence the amount of

73 dissolved organic carbon (DOC), dissolved oxygen, and bacterial abundance in the surrounding water

74 (Haas et al., 2011). Fleshy macroalgae and algal turfs release more DOC than coral and have higher

75 microbial growth in the surrounding water column (Wild et al., 2010; Haas et al., 2011; Haas et al.,

76 2013b). Turf algae, dominated by filamentous cyanobacteria, produce more DOC than other reef macro-

77 organisms and can generate nearly $80 \%$ of all DOC on a reef (Brocke et al., 2015).

79 The increase of DOC in the water column can lead to a reduction of certain microbial taxa and stimulation 80 of other microbial groups (Nelson et al., 2013). An in vitro experiment showed that the water column, that 81 was dominated by oligotrophic microbial genera Synechococcus and Pelagibacter, became dominated by 82 the family Vibrionaceae and genera Pseudoalteromonas, Aeromonas, and Flavobacterium when exposed 83 to exudates from algae (Nelson et al., 2013). In contrast, the phylum Planctomycetes and families

84 Bacteriovoraceae, Erythrobacteraceae, Kordiimonadaceae, and Hyphomonadaceae were the dominant 85 microbial taxa when exposed to exudates from coral (Nelson et al. 2013). In situ studies also demonstrate a correlation between reef macro-organism cover and microbial community taxa in the water column

87 (Dinsdale et al., 2008a; Kelly et al., 2014; Tout et al., 2014). Microbial communities on coral-dominated reefs show a higher proportion of sequences similar to phyla Cyanobacteria and Firmicutes, and class Alphaproteobacteria. In contrast, reefs with high algae cover (up to $68 \%$ ) and low coral cover have ten times the microbial abundance compared to a coral-dominated reef, with a higher proportion of sequences similar to phylum Bacteroidetes, classes Gammaproteobacteria and Betaproteobacteria, and opportunistic pathogens from the Vibrio genera (Dinsdale et al., 2008a; Bruce et al., 2012; Kelly et al., 2014). On a broader scale, the microbial communities above a healthy reef can be described as copiotrophic in general, whereas microbial communities adjacent to the reef above a sandy substrate, or in open water off the reef are described as more oligotrophic (Tout et al. 2014).

Microbial community characteristics vary across coral reefs and among sites within reefs, and these changes correlate with coral cover (Kelly et al., 2014; Tout et al., 2014). Because of the interactions between a benthic organism and the surrounding water layers, we hypothesized that within a single reef

$100\left(\leq 50 \mathrm{~m}^{2}\right)$ there will be a mosaic pattern of microbial communities in the boundary layers surrounding 101 each benthic organism. We propose that each benthic organism influences the microbiome in the water 102 column boundary layers, promoting a benthic organism-specific microbial community that we call the 
103 'aura-biome'. To test our aura-biome hypothesis, we take a shotgun metagenomics approach (Dinsdale et

104 al., 2008b) and describe the microbial communities in the water column directly above and around

105 (momentum and diffusive boundary layers) different benthic reef organisms. We tested multiple benthic

106 organisms, including coral, fleshy macroalgae, turf algae, and zoanthids on a single reef of the Abrolhos

107 Bank in the South Atlantic.

108

109

\section{Methods}

111

112 Field site: We conducted the study on the Abrolhos Bank coral reefs, which are situated on a 45,000 $\mathrm{km}^{2}$ 113 expansion of the continental shelf in the southern Bahia state of Brazil. The Abrolhos Bank supports the 114 largest coral reefs in the South Atlantic, but coral cover has declined over the last decade (Francini-Filho 115 et al., 2008; Francini-Filho et al., 2013). We focused our study on the reefs surrounding Ilha Santa

116 Bárbara (-18.033333, -38.6668038), which is in a marine protected area. The island is about $60 \mathrm{~km}$ from

117 the coast with no agricultural runoff, and housing for about 10 people. The reef site was approximately 50

$118 \mathrm{~m}^{2}$, within which we sampled the water column above replicate patches of each dominant organism. The 119 sampling was conducted over two days (23 and 24 June 2014). The first dive was in the afternoon of $23^{\text {rd }}$

120 June, and the second and third dives were in the morning and afternoon of $24^{\text {th }}$ June. Three separate

121 sampling dives were taken to allow time to filter the water for microbial collection. The research was

122 conducted under a federal government license (SISBIO no. 10112 - 2). We received this license to access

123 protected areas from Parque Nacional Marinho de Abrolhos/IBAMA (Instituto Brasileiro do Meio

124 Ambiente e dos Recursos Naturais Renova'veis).

125

126 Collection of water was conducted on small patches of the reef where a single macro-organism dominated

127 the benthos. A $1 \mathrm{~m}^{2}$ quadrat was placed haphazardly on selected patches and multiple photographs were

128 taken of each sampling plot. Care was taken when placing the quadrat to not cause excessive water

129 movement and disturbance the boundary layers. Photographs were taken of each quadrat and 30 points

130 within the plot were measured to determine the percent cover of the benthic organism in each plot (Figure

131 1). A Manta2 Series Multiprobe ${ }^{\mathrm{TM}}$ handheld data logging instrument was placed on the surface of the

132 benthic organism to log water physio-chemistry on each dive (Figure S1).

133

134 Microbial sampling technique: Microbial samples were collected using a bilge pump and bag unit.

135 Approximately $20 \mathrm{~L}$ of water was pumped directly off the benthic surface (the pump was held about $1 \mathrm{~cm}$ 136 above the surface of the organism, but no further than $5 \mathrm{~cm}$ above the surface). The end of the bilge was 
137 placed 1-5 cm directly above the substrate, making sure the pump did not touch the reef macro-organism.

138 The water collected was a combination of the diffusive and momentum boundary layers, as described in

139 Barott and Rohwer (2013), and makes up the aura-biome. In addition, $4 \mathrm{~cm}$ above a coral was identified

140 as the location with the highest abundance of heterotrophic bacteria (Seymour et al., 2005), and this local

141 maxima was targeted by the sampling. The water surrounding 4 distinct macro-organisms was collected

142 for metagenome construction. The 4 reef macro-organisms included; 1) coral (Mussismilia braziliensis) (n

143 =4), 2) fleshy macroalgae, characterized by numerous genera, including Stypopodium, Dictyota and

144 Canistrocarpus $(\mathrm{n}=3), 3)$ benthic turf algae, characterized by closely cropped long red filaments of both

145 red algae and cyanobacterial mats $(\mathrm{n}=3), 4)$ zoanthid (Palythoa caribaeorum) $(\mathrm{n}=2)$, and we also

146 collected water column samples (facing the open ocean $\sim 3$ meters above the reef) $(n=4)$. The 4 reef

147 organisms and water column samples are our treatments for the statistical analysis and the number of

148 replicate organisms is given in parenthesis and the total number of metagenomes constructed was 16.

150 Water collected above each macro-organism was transferred to niskin bottles using a $20 \mu \mathrm{m}$ filter to

151 remove larger organisms, such as diatoms and phytoplankton. The microbes collected from all 20 liters

152 were pressure driven by compressed air through a $0.22 \mu \mathrm{m}$ sterivex filter. Water from all samples was

153 collected in duplicate sterivexes, except the turf algae water samples, which were each collected on a

154 single sterivex. Sterivexes were wrapped with parafilm, placed in a ziploc bag, and stored in liquid

155 nitrogen until extraction of DNA.

156

157

DNA extraction and sequencing: Microbial DNA was extracted from sterivex filters with lysis buffer and proteinase K (Bruce et al., 2012) and purified using the Nucleospin Tissue column purification protocol (Macherey Nagel, Germany). Extracted and purified DNA was quantified using a Qubit (Life

160 Technologies, USA) to ensure that each sample contains the minimum amount of DNA required for 161 sequencing. Shotgun metagenomics, a proven technique used to describe microbial communities

162 (Dinsdale et al., 2008a\&b; Hugenholtz and Tyson, 2008; Kelly et al., 2014; Haggerty and Dinsdale,

163 2017), was used to explain the taxonomy and functional pathways present in the microbes from each

164 parcel of water. Shotgun metagenomes are sequenced without amplification or primers, such that a

165 random selection of the microbial DNA including all gene areas are sequenced, and identified using

166 bioinformatics techniques (described below). Following Illumina protocols, metagenomic libraries were

167 created from each sample using $100 \mathrm{ng}$ of starting input DNA using the TruSeq DNA PCR-Free Library

168 Preparation Kit. Libraries were paired-end sequenced on an Illumina MiSeq with a v3 600-cycle reagent 169 kit. 
171 Metagenomic analysis: Metagenomic sequences were run through the bioinformatics tool PRINSEQ to

172 remove and trim any low quality sequences, including exact duplicates, those that contained N's, and

173 sequences that had a Q-score of less than 20 (Schmieder and Edwards 2011). Sequences were uploaded to

174 the Metagenomics Rapid Annotation Server (MG-RAST) for taxonomic and functional annotation

175 (Meyer et al., 2008), using the minimum cutoff parameters of 1x10-5 e-value (Bruce et al., 2012; Garcia et

176 al., 2013), $70 \%$ identity, and alignment length of 30 nucleotides. These parameters are identified as

177 providing a conservative estimate of both the taxa and function. MG-RAST compares the sequences from

178 the metagenome to the database to identify the best hit classification within the database (Meyer et al.,

179 2008). Taxonomic classifications used the SEED database as a reference, while functional classifications

180 used SEED's Subsystem Annotation. The SEED annotation describes metabolic processes in a

181 hierarchical scheme (Overbeek et al., 2005).

182

183 Statistical analysis of the metagenomes: The microbial communities were described by comparing the

184 proportion of sequences that matched each microbial organism in each metagenome. First, we described

185 the proportion of sequences at the domain level. Second, we described the genera present in each

186 metagenome. Third, we described the proportion of sequences in the most abundant 20 genera that vary

187 across the treatments, or aura-biomes. The functions in the microbial community were compared by

188 investigating the proportion of sequences similar to each metabolic group. The SEED follows a

189 hierarchical scheme, which includes broad metabolic groups, such as carbohydrate metabolism, and these

190 groups are broken down into specific subsystems, for example carbon monoxide dehydrogenase. We

191 tested whether the proportion of sequences in each genera or metabolism varied between aura-biomes

192 using an analysis of variance (ANOVA) with a post-hoc Tukey test. Statistical analysis was conducted on

193 the Statistical Analysis of Metagenomic Profiles (STAMP) package (Parks and Beiko, 2010).

194

195 To visualize whether the microbial community above each macro-organism had a distinguishing

196 taxonomic or functional profile, two canonical discriminant analyses (CDA) were conducted using SPSS,

197 similar to techniques described in Dinsdale et al. (2013). CDAs use linear correlations of variables, in this

198 case taxa or function, that drives the differences within treatments (Dinsdale et al., 2013). The position of

199 each metagenome reflects the frequency combination of sequences associated with each variable; the

200 vectors indicate which variable determines the distribution of metagenomes. Metabolisms that showed a

201 statistical difference between treatments were explored further by comparing differences in the proportion

202 of sequences in each gene pathway using an ANOVA with a post-hoc Tukey test within STAMP.

203

204 Results 
206 Four groups of benthic macro-organisms, coral $(\mathrm{n}=4)$, fleshy macroalgae $(\mathrm{n}=3)$, turf algae $(\mathrm{n}=3)$, and 207 zoanthid $(\mathrm{n}=2)$ were surveyed at the Ilha Santa Barbára reef site $\left(\leq 50 \mathrm{~m}^{2}\right)$ for percent benthic cover, 208 surrounding water physiochemical properties, and boundary layer microbial community structure (Figure 209 1, Table S1). We also included a fifth treatment group with samples collected from the open water 210 column off the reef $\left(\sim 3 \mathrm{~m}\right.$ above the reef $\left.\mathrm{n}_{\text {total }}=16\right)$. Mean benthic percent cover was calculated from 211 quadrat images taken for each replicated macro-organism group. For the four groups, coral had a mean 212 cover of $78.3 \pm 2.9 \%$, fleshy macroalgae had a mean cover of $93.8 \pm 2.3 \%$, turf algae had a mean cover 213 of $83.3 \pm 3.3 \%$, and zoanthid had a mean cover of $88.3 \pm 5.0 \%$ on the benthos. During the three dives, 214 the water was characterized by a mean temperature of $25.36 \pm 0.09{ }^{\circ} \mathrm{C}, \mathrm{pH}$ of $8.18 \pm 0.03$, chlorophyll 215 concentration of $2.96 \pm 0.44(\mu \mathrm{g} / \mathrm{l})$, and dissolved oxygen of $107.22 \pm 3.56 \%$ saturation and $7.09 \pm 0.23$ $216 \mathrm{mg} / 1$ (Figure S1).

218 Constructed metagenomes averaged 1,294,121 sequences per metagenome with each sequence having an average length of $277 \pm 82 \mathrm{bp}$ (Table S2). Bacteria was the most abundant domain in the metagenomes, averaging $92.5 \pm 0.5 \%$ of sequences across all samples (Figure S2), and was not significantly different in any treatment $(\mathrm{p}=0.053)$. In the metagenomes collected above zoanthid, domain Eukaryota was significantly higher than in the metagenomes collected above turf algae $(p<0.05)$. Viruses were more abundant in the metagenomes from the water column, coral, and turf algae treatments $(p<0.05)$ compared with the other 2 treatments. Because the total abundance of Eukaryota and viruses in the metagenomes accounted for only $3.16 \%$ of the annotated sequences, we did not investigate further, but instead focused the analysis on the domain Bacteria. Within Bacteria, sequences matched to the phylum Proteobacteria were six times higher $(63.4 \pm 6.7 \%$ of the metagenomes $)$ than the second most abundant phylum, Cyanobacteria $(10.7 \pm 3.1 \%)$, and third most abundant phylum, Bacteroidetes $(10.0 \pm 1.5 \%)$

229 (Figure S3).

230

Of the 347 bacterial genera found across all treatments (Table S3), the twenty most abundant genera represented $59.5 \%$ of all sequences and were investigated further (Figure 2). Candidatus Pelagibacter was the most abundant genus within all samples and was the most abundant genus in the coral aura-biome $(17.2 \pm 5.8 \%)$ and the water column $(14.3 \pm 4.2 \%)$ treatments. Alteromonas was the most abundant genus in the zoanthid aura-biome (27.2 $\pm 8.9 \%)$. Synechococcus had high proportions of sequences in both the coral aura-biome and water column microbiome $(14.3 \pm 5.9 \%)$. Vibrio was the most abundant genus in the turf algae aura-biome $(11.0 \pm 8.8 \%)$. Of the top twenty genera, only Alteromonas was significantly different between treatments $\left(\right.$ ANOVA $\left._{d f=4}=4.761 \mathrm{p}=0.018\right)$. The proportion of 
239 sequences of Alteromonas was significantly higher in the zoanthid aura-biome compared with the fleshy

240 macroalgae aura-biome (Tukey $\mathrm{p}=0.020)$, turf algae aura-biome (Tukey $\mathrm{p}=0.015$ ), and water column

241 (Tukey $\mathrm{p}=0.046)$.

242

243 A CDA conducted on the twenty most abundant genera showed the metagenomes group together based

244 on the macro-organism they were collected above and axis 1 and 2 explained $81.2 \%$ of the variance

245 between treatments (Figure 3). The separation of the turf algae aura-biome is driven by abundance of

246 genera Vibrio and Flavobacterium, while zoanthid was driven by the abundance of Alteromonas. The

247 separation of the fleshy macroalgae aura-biome was driven by the abundance of genera Ruegeria and

248 Roseovarius, while coral was influenced by the abundance of Synechococcus. The water column appeared

249 to be the most dissimilar treatment compared to the four macro-organism treatments, and was driven by

250 many genera including Synechococcus, Shewanella, and Leeuwenhoekiella.

251

252 Microbial metagenomes were compared for their metabolic annotation at broad functional levels down to

253 specific pathways. At the broadest level there were 27 functional subsystems, with the most abundant

254 metabolic pathways across all treatments being amino acids and derivatives $(12.5 \pm 0.1 \%)$, carbohydrates

$255(12.4 \pm 0.1 \%)$, protein metabolism $(7.3 \pm 0.1 \%)$, and cofactors, vitamins, prosthetic groups and pigments

$256(6.4 \pm 0.1 \%)$ (Figure 4). Of the 27 broad metabolisms, five were significantly different between aura-

257 biomes. Membrane transport (ANOVA $\mathrm{F}_{d f=4}=3.618, \mathrm{p}=0.041$ ) was significantly higher in zoanthid

258 aura-biomes compared with the coral aura-biome (Tukey $\mathrm{p}=0.045)$ and the water column (Tukey $\mathrm{p}=$

259 0.035). The zoanthid aura-biome had a significantly higher abundance of genes within the phages,

260 prophages, transposable elements, and plasmids subsystem ( ANOVA $_{d f=4}=6.636, \mathrm{p}=0.006$ ) compared

261 with all other treatments (Tukey macroalgae $p=0.046$, coral $p=0.004$ ), turf algae $p=0.014$, water

262 column $\mathrm{p}=0.007)$. The fleshy macroalgae aura-biomes had a significantly lower abundance of genes

263 within phosphorus metabolism (ANOVA $\left.\mathrm{F}_{d f=4}=7.276, \mathrm{p}=0.004\right)$ compared with the water column

264 (Tukey $p=0.022$ ), and aura-biomes of zoanthid (Tukey $p=0.006)$ and turf algae (Tukey $p=0.006)$. The

265 zoanthid aura-biomes were significantly lower in protein metabolism genes $\left(\right.$ ANOVA $_{d f=4}=4.234 \mathrm{p}=$

$2660.026)$ compared to the water column (Tukey $\mathrm{p}=0.021)$. The respiration pathway $\left(\right.$ ANOVA $_{d f=4}=$

$2675.617, \mathrm{p}=0.010$ ) varied between treatments with zoanthid (Tukey $\mathrm{p}=0.015$ ) and fleshy macroalgae

268 (Tukey $\mathrm{p}=0.027$ ) aura-biomes have significantly higher genes compared with the turf algae aura-biomes.

270 Similar to the taxonomic analysis, a CDA was constructed for the metabolic analysis using the proportion

271 of metagenomic sequences annotated to the 27 broad functional subsystems. The CDA showed that

272 metagenomes collected above each macro-organism group together by treatment, and the two axes 
273 explained $93.7 \%$ of the variance between treatments (Figure 5). Metabolisms including cell division and

274 cell cycle, dormancy and sporulation, motility and chemotaxis, and cofactors, vitamins, prosthetic groups

275 and pigments were overrepresented in the coral aura-biome. Potassium metabolism was overrepresented

276 in the fleshy macroalgae aura-biome. The sulfur, phosphorus, secondary metabolism, and virulence,

277 disease and defense were overrepresented in the turf algae aura-biome. Stress response, respiration, and

278 membrane transport metabolisms were overrepresented in the zoanthid aura-biome. Nucleosides and

279 nucleotides, and regulation and cell signaling were overrepresented in the water column metagenomes.

280 Each of these broad pathways contained more specific functions that varied by treatment, which was

281 analyzed further (Table 1).

282

283 The coral aura-biome had seven specific metabolisms that were overrepresented within six broad level

284 functions. Six specific pathways overrepresented in the coral aura-biome were also overrepresented in the

285 water column samples, and included methicillin resistance, DNA repair base excision, Pterin metabolism

286 3, Riboflavin to FAD and YgfZ. De Novo purine biosynthesis, and Mnm5U34 biosynthesis. Pathways

287 that were exclusively overrepresented in the water column included YgjD and YeaZ, and tRNA.

288

289

The fleshy macroalgae aura-biome had two pathways associated with respiration that were

290 overrepresented - carbon monoxide dehydrogenase maturation factors and methanogenesis strays (Table

291 1). The turf algae aura-biome had another 10 pathways that were overrepresented, 8 of which were within

292 the membrane transport pathway, one within the respiration pathway, and one within the nucleoside and

293 nucleotide pathway. These included NhaA, NhaD and sodium-dependent phosphate transporters; fructose

294 and mannose inducible PTS; galactose-inducible PTS; sucrose-specific PTS; phosphoglycerate transport

295 system; type III secretion; pyrimidine conversions; and tetrathionate respiration. Finally, Fap amyloid

296 fiber secretion and general secretion were overrepresented in both the turf algae and zoanthid aura-

297 biomes.

298

299

The zoanthid aura-biome had 16 specific pathways that were overrepresented in nine broad metabolisms

300

(Table 1). The specific pathways overrepresented include Phd-Doc, YdcE-YdcD toxin/antitoxin, purine

301 utilization, bacterial hemoglobins, universal stress protein family, respiratory dehydrogenases I, terminal

302 cytochrome $\mathrm{C}$ oxidases, adhesions, arsenic resistance, phosphate uptake, phosphate-binding DING

303 proteins, group II intron-associated genes, polyadenylation specificity factors, RNA polymerase III

304 initiation factor, and 2-phosphoglycolate salvage.

305

306 Discussion 
Water column microbiomes are correlated with cover of benthic organisms between reefs (Dinsdale et al., 2008a; Kelly et al., 2014; Haas et al., 2016; Tout et al., 2014). Here we show that the relationship between microbes and benthic macro-organisms occurs within a single reef, where the boundary layer aura-biome,

311 defined here as the water directly above and around a macro-organism, follows a mosaic pattern of the

312 dominant benthic organism. Coral cover in the Abrolhos Island reefs varies from 3 - 39 \% (Oigman-

313 pszczol and Creed, 2004; Leao et al., 2010; Francini-filho et al., 2013). We exploited the variations in

314 benthic cover to show that the microbial community in the water above replicate patches varied

315 depending on the dominant benthic organism.

317 The microbial communities present in the boundary layer above the host organism reflect a combination 318 of environmental parameters, including the nutrients in the water column, the chemicals and microbes 319 released by macro-organisms, as well as the abundance of predators and the water dynamics (i.e. tides, 320 currents, and waves) (Haas et al., 2011; Garren and Azam 2012). The genera and metabolic pathways 321 present in the microbial communities in each of the aura-biomes provides insight into the micro322 environment that is developing around each macro-organism (Figure 6).

324 The functional repertoire in microbes above coral, including Riboflavin RNA processing and folate and pterines, were functions that suggest oxygenating growth; while the fleshy macroalgae aura-biome had enrichment in functions suggesting anoxic growth, such as methanogenesis and carbon monoxide dehydrogenase pathways, which are often found in anaerobic bacteria (Thauer, 1998). Previous studies

328 have shown that microbial oxygen consumption differs between exposure to exudates from algae versus exudates from coral (Haas et al., 2013b). In an incubation study conducted on exudates derived from fleshy algae, microbial communities were stimulated and able to drawdown the dissolved organic carbon, whereas the coral exudate increased the dissolved organic carbon levels during the day (Haas et al. 2013b). Our results suggest that small patches of benthic fleshy macroalgae are creating anaerobic conditions within their aura-biome. While hypoxia was not measured in this experiment, direct measurements conducted in Haas et al. (2013a) documented lower oxygen rates above fleshy macroalgae. Together, these findings suggest that the fleshy macroalgae aura-biome has different oxygen content versus the coral aura-biome or open water column. organic carbon (Brocke et al., 2015). In our experiment, the metagenomes constructed from the turf algae aura-biome, included two specific heterotrophic bacterial genera, Vibrio and Flavobacterium, suggesting 
341 a high amount of organic carbon is being released by the turf algae. The Flavobacterium genera includes

342 bacterial pathogens known to cause disease in trout (Crump et al., 2001), while many species of Vibrio

343 are well-known pathogens associated with declines in coral health, coral bleaching, and diseases

344 (Kushmaro et al., 2001; Cervino et al., 2004; Rosenberg and Falkovitz 2004; Cervino et al., 2008). In our

345 study, one of the metagenomes above the turf algae had $28.7 \%$ of sequences showing similarity to Vibrio.

346 Other studies found that Vibrio made up 30-60\% of a cultured microbiome of diseased coral (Ritchie et

347 al., 1994; McGrath and Smith 1999) and up to $80 \%$ of taxa from metagenomes constructed from stressed

348 corals (Thurber et al., 2009).

350 In addition to the increase in proportions of heterotrophic taxa in the turf algae metagenomes, a higher

351 proportion of sequences were associated with carbohydrate metabolisms The presence of the carbohydrate

352 metabolism suggests that these microbes were rapidly consuming the large amounts of dissolved organic

353 carbon, which is being secreted into the water by the turf algae (Brocke et al. 2015). The increase of type

354 II, III and IV secretion systems suggest that the microbes had functions that are often used in cell-to-cell

355 and host-microbe interactions (Christie, 2001; Alfano and Collmer, 2004; Cianciotto, 2005). Given the

356 high proportion of heterotrophs and potential pathogens and the increase of secretion systems, the aura-

357 biome produced by the turf algae may be detrimental to the health of adjacent organisms.

358

359 Zoanthids had the most distinctive aura-biome compared to the other treatments. Previous researchers

360 have measured lower DOC production rates from zoanthids compared to algae and coral (Silveira et al.,

361 2015). Therefore, we suggest that unlike the pattern observed with turf algae, where high DOC production

362 drives a shift in the aura-biome composition, other exudates from the macro-organism may be influencing

363 the observed changes in the microbial community above the zoanthid.

364

365 The zoanthid aura-biomes were enriched in Pseudoalteromonas and Alteromonas, which have been

366 negatively associated with coral cover (Kelly et al., 2014). The Pseudoalteromonas genus includes

367 potential coral pathogens (Ritchie, 2006), and some Alteromonas species are associated with coral yellow

368 band disease (Sweet et al., 2013). The functions induced in the zoanthid aura-biome included type II and

369 VIII secretion systems, toxin/antitoxin system, resistance to antibiotics and toxic compounds, and DNA

370 repair (Figure 6). Type II and VIII secretion systems are often found in pathogenic microbes (Olsén et al.,

371 1989; Collinson et al., 1991; Sandkvist 2001). Toxin/antitoxin gene pathways are a response to stress,

372 with $\mathrm{YdcE}$ as the toxin and $\mathrm{YdcD}$ as the inhibitor to the toxin (Pellegrini et al., 2005). Zoanthids contain a

373 potent toxin, palytoxin (Moore and Scheuer, 1971), and bacteria isolated from zoanthid display the

374 presence of this hemolytic toxin as well (Seemann et al., 2009). The release of these toxin-forming 
375 microbes from the organism's surface, as well as the toxin directly from zoanthid, may be causing a more

376 stressful environment and the enhancement of the toxin/antitoxin pathways in the aura-biome. The

377 increase of Pseudoalteromonas and Alteromonas in the water column surrounding the zoanthid may be

378 another factor enabling the already documented aggressive zoanthid species to form large

379 monophylogenetic stands (Suchanek and Green, 1981; Bastidas and Bone, 1996; Francini-Filho and

380 Moura, 2010).

381

382 The separation between aura-biomes was not absolute. Twenty liters of water was collected, with mixing 383 occurring from the surrounding water during the sampling procedure. Despite the potential mixing of the

384 boundary layer and surrounding water, each aura-biome showed a varying proportion of taxa and

385 functions in the metagenomes (Figure 6). The coral and water column metagenomes shared many genera 386 found on coral reefs from around the world (Ritchie 2006; Wegley et al., 2007; Bruce et al., 2012). The

387 aura-biome induced by the turf algae was driven by an abundance of Vibrio, Flavobacterium and

388 Rhodopirellula, which is consistent with previous metagenomic descriptions of microbes present on

389 degraded coral reefs (Dinsdale et al. 2008a). Zoanthids are a dominant organism on Brazilian coral reefs;

390 these organisms are aggressive in their ability to monopolize reef space and prohibit recruitment of other 391 species (Mendonça-Neto and da Gama, 2009). The ability of zoanthid to influence the microbes in the 392 surrounding water could be an additional invasive mechanisms.

393

394 Conclusion

395

396 The exudates from the benthic reef organisms are influencing the microbial community in the water 397 column immediately surrounding the macro-organism, creating a unique aura-biome. A combination of 398 these aura-biomes make up the microbiome of a reef. Each aura-biome possesses functions which may 399 drive interactions with their neighboring organisms, and some of these interactions may be negative.

400 Therefore, as the benthic cover on a coral reef changes, the microbial community is also changing and 401 may affect the ability of benthic organisms to recruit and grow on the reef.

402

\section{Data Accessibility}

404

405 All metagenomes will be available on MG-RAST and MG-RAST ids are included in Supplementary 406 Table 2.

407

408 References 
Alfano, J. R., and A. Collmer. 2004. Type III secretion system effector proteins: Double agents in bacterial disease and plant defense. Annual Review Phytopathology 42:385-414.

Bastidas, C., and D. Bone. 1996. Competitive strategies between Palythoa caribaeorum and Zoanthus sociatus (Cnidaria: Anthozoa) at a reef flat environment in Venezuela. Bulletin of Marine Science 59:543-555.

Barott, K. and F. Rohwer. 2013 Unseen players shape benthic competition on coral reefs. Trends in Microbiology 12:621-628

Brocke, H. J., F. Wenzhoefer, D. De Beer, B. Mueller, F. C. Van Duyl, and M. M. Nugues. 2015. High dissolved organic carbon release by benthic cyanobacterial mats in a Caribbean reef ecosystem. Scientific Reports 5:8852. doi: 10.1038/srep08852.

Bruce, T., P. M. Meirelles, G. Garcia, R. Paranhos, C. E. Rezende, R. L. de Moura, R.-F. Filho, E. O. C. Coni, A. T. Vasconcelos, G. Amado Filho, M. Hatay, R. Schmieder, R. Edwards, E. Dinsdale, and F. L. Thompson. 2012. Abrolhos Bank reef health evaluated by means of water quality, microbial diversity, benthic cover, and fish biomass data. PLoS One 7:e36687.

Cantera, K., R. Jaime, C. Orozco, E. Londoño-Cruz, and G. Toro-Farmer. 2003. Abundance and distribution patterns of infaunal associates and macroborers of the branched coral (Pocillopora damicornis) in Gorgona Island (eastern tropical Pacific). Bulletin of Marine Science 72:207-219.

Cervino, J. M., R. L. Hayes, S. W. Polson, S. C. Polson, T. J. Goreau, R. J. Martinez, and G. W. Smith. 2004. Relationship of Vibrio species infection and elevated temperatures to yellow blotch / band disease in Caribbean corals. Applied Environmental Microbiology 70:6855-6864.

Cervino, J. M., F. L. Thompson, E. A. Lorence, T. J. Goreau, and R. L. Hayes. 2008. The Vibrio core group induces yellow band disease in Caribbean and Indo-Pacific reef-building corals. Journal of Applied Microbiology 105:1658-1671.

Christie, P. J. 2001. Type IV secretion: Intercellular transfer of macromolecules by systems ancestrally related to conjugation machines. Molecular Microbiology 40:294-305.

Cianciotto, N. P. 2005. Type II secretion: a protein secretion system for all seasons. Trends in Microbiology 13:581-588.

Collinson, S., L. Emödy, K. Müller, and W. Kay. 1991. Purification and characterization of thin, aggregative fimbriae from Salmonella enteritidis. Journal of Bacteriology 173:4773-4781.

Crump, E. M., M. B. Perry, S. C. Clouthier, and W. W. Kay. 2001. Antigenic characterization of the fish pathogen Flavobacterium psychrophilum. Applied and Environmental Microbiology 67:750-759.

De'ath, G., J. M. Lough, and K. E. Fabricius. 2009. Declining coral calcification on the Great Barrier Reef. Science 323:116-119.

Dinsdale, E. A., R. A. Edwards, B. Bailey, I. Tuba, S. Akhter, K. McNair, R. Schmieder, N. Apkarian, M. Creek, and E. Guan. 2013. Multivariate analysis of functional metagenomes. Frontiers in Genetics 4:41.

Dinsdale, E. A., O. Pantos, S. Smriga, R. A. Edwards, F. Angly, L. Wegley, M. Hatay, D. Hall, E. Brown, M. Haynes, L. Krause, E. Sala, S. A. Sandin, R. V. Thurber, B. L. Willis, F. Azam, N. Knowlton, and F. Rohwer. 2008a. Microbial Ecology of Four Coral Atolls in the Northern Line Islands. Plos One 3.

Dinsdale, E. A., R. A. Edwards, D. Hall, F. Angly, M. Breitbart, J. M. Brulc, M. Furlan, C. Desnues, M. Haynes, and L. Li. 2008b. Functional metagenomic profiling of nine biomes. Nature 452:629632.

Dinsdale, E. A., and F. Rohwer. 2011. Fish or Germs? Microbial dynamics associated with changing trophic structures on coral reefs. Pages 231-240 in Z. Dubinsky and N. Stambler, editors. Coral Reefs: An ecosystem in transition. Springer Netherlands, Dordrecht.

Egan, S., T. Harder, C. Burke, P. Steinberg, S. Kjelleberg, and T. Thomas. 2013. The seaweed holobiont: understanding seaweed-bacteria interactions. FEMS Microbiology Reviews 37:462-476. 
458

459

460

461

462

463

464

465

466

467

468

469

470

471

472

473

474

475

476

477

478

479

480

481

482

483

484

485

486

487

488

489

490

491

492

493

494

495

496

497

498

499

500

501

502

503

504

505

506

507

508

Francini-Filho, R. B., R. L. Moura, F. L. Thompson, R. M. Reis, L. Kaufman, R. K. P. Kikuchi, and Z. M. a. N. Leão. 2008. Diseases leading to accelerated decline of reef corals in the largest South Atlantic reef complex (Abrolhos Bank, eastern Brazil). Marine Pollution Bulletin 56:1008-1014.

Francini-Filho, R. B., and R. L. d. Moura. 2010. Predation on the toxic zoanthid Palythoa caribaeorum by reef fishes in the Abrolhos Bank, eastern Brazil. Brazilian Journal of Oceanography 58:77-79.

Francini-Filho, R. B., E. O. C. Coni, P. M. Meirelles, G. M. Amado-filho, F. L. Thompson, G. H. Pereirafilho, A. C. Bastos, D. P. Abrantes, P. Y. G. Sumida, N. L. Oliveira, C. M. Ferreira, F. Z. Gibran, A. Z. Gu, L. Kaufman, C. V. Minte-vera, and R. L. Moura. 2013. Dynamics of coral reef benthic assemblages of the Abrolhos Bank, eastern Brazil: Inferences on natural and anthropogenic drivers. Plos One 8:1-12.

Garcia, G. D., G. B. Gregoracci, E. De O Santos, P. M. Meirelles, G. G. Z. Silva, R. Edwards, T. Sawabe, K. Gotoh, S. Nakamura, T. Iida, R. L. De Moura, and F. L. Thompson. 2013. Metagenomic analysis of healthy and white plague-affected Mussismilia braziliensis Corals. Microbial Ecology 65:1076-1086.

Garren, M., and F. Azam. 2012. Corals shed bacteria as a potential mechanism of resilience to organic matter enrichment. The ISME journal 6:1159-1165.

Haas, A. F., C. Jantzen, M. S. Naumann, R. Iglesias-Prieto, and C. Wild. 2010. Organic matter release by the dominant primary producers in a Caribbean reef lagoon: Implication for in situ $\mathrm{O} 2$ availability. Marine Ecology Progress Series 409:27-39.

Haas, A. F., C. E. Nelson, L. W. Kelly, C. a. Carlson, F. Rohwer, J. J. Leichter, A. Wyatt, and J. E. Smith. 2011. Effects of coral reef benthic primary producers on dissolved organic carbon and microbial activity. PLoS One 6.

Haas, A. F., A. K. Gregg, J. E. Smith, M. L. Abieri, M. Hatay, and F. Rohwer. 2013a. Visualization of oxygen distribution patterns caused by coral and algae. PeerJ 1:e106.

Haas, A. F., C. E. Nelson, F. Rohwer, L. Wegley-Kelly, S. D. Quistad, C. A. Carlson, J. J. Leichter, M. Hatay, and J. E. Smith. 2013b. Influence of coral and algal exudates on microbially mediated reef metabolism. PeerJ 1:e108.

Haas, A. F., M. F. Fairoz, L. W. Kelly, C. E. Nelson, E. A. Dinsdale, R. A. Edwards, S. Giles, M. Hatay, N. Hisakawa, and B. Knowles. 2016. Global microbialization of coral reefs. Nature Microbiology 1:16042.

Haggerty, J. M., and E. A. Dinsdale. 2017. Distinct biogeographical patterns of marine bacterial taxonomy and functional genes. Global Ecology and Biogeography. 26, 177-190

Harder, T., A. H. Campbell, S. Egan, and P. D. Steinberg. 2012. Chemical mediation of ternary interactions between marine holobionts and their environment as exemplified by the red alga Delisea pulchra. Journal of Chemical Ecology 38:442-450.

Hixon, M. A., and J. P. Beets. 1993. Predation, prey refuges, and the structure of coral reef fish assemblages Behavioral Ecology and Sociobiology 33:305-312.

Hoegh-Guldberg, O., P. J. Mumby, a. J. Hooten, R. S. Steneck, P. Greenfield, E. Gomez, C. D. Harvell, P. F. Sale, A. J. Edwards, K. Caldeira, N. Knowlton, C. M. Eakin, R. Iglesias-Prieto, N. Muthiga, R. H. Bradbury, A. Dubi, and M. E. Hatziolos. 2007. Coral reefs under rapid climate change and ocean acidification. Science 318:1737-1742.

Hugenholtz, P., and G. W. Tyson. 2008. Microbiology: metagenomics. Nature 455:481-483.

Hughes, T. P. 1994. Catastrophes, phase shifts, and large-scale degradation of a Caribbean coral reef. Science 265:1547-1551.

Hughes, T. P., N. a. J. Graham, J. B. C. Jackson, P. J. Mumby, and R. S. Steneck. 2010. Rising to the challenge of sustaining coral reef resilience. Trends in Ecology \& Evolution 25:633-642.

Hughes, T. P., M. J. Rodrigues, D. R. Bellwood, D. Ceccarelli, O. Hoegh-guldberg, L. Mccook, N. Moltschaniwskyj, M. S. Pratchett, R. S. Steneck, and B. Willis. 2007. Phase shifts, herbivory, and the resilience of coral reefs to climate change. Current Biology 17:360-365.

Jackson, J. B. C., and L. E. O. Buss. 1975. Allelopathy and spatial competition among coral reef invertebrates. Proceedings of the National Academy of Science 72:5160-5163.

PeerJ reviewing PDF | (2016:10:13683:2:2:ACCEPTED 16 Jul 2017) 
509

510

511

512

513

514

515

516

517

518

519

520

521

522

523

524

525

526

527

528

529

530

531

532

533

534

535

536

537

538

539

540

541

542

543

544

545

546

547

548

549

550

551

552

553

554

555

556

557

558

559

Kelly, L. W., G. J. Williams, K. L. Barott, C. A. Carlson, E. A. Dinsdale, R. A. Edwards, A. F. Haas, M. Haynes, Y. W. Lim, T. McDole, C. E. Nelson, E. Sala, S. A. Sandin, J. E. Smith, M. J. A. Vermeij, M. Youle, and F. Rohwer. 2014. Local genomic adaptation of coral reef-associated microbiomes to gradients of natural variability and anthropogenic stressors. Proceedings of the National Academy of Sciences of the United States of America 111:10227-10232.

Kushmaro, A., E. Banin, Y. Loya, E. Stackebrandt, and E. Rosenberg. 2001. Vibrio shiloi sp . nov ., the causative agent of bleaching of the coral Oculina patagonica. International Journal of Systematic and Evolutionary Microbiology 129:1383-1388.

Leao, R. K. P. Kikuchi, M. D. M. Oliveira and V. Vasconcellos 2010 Status of Eastern Brazilian coral reefs in time of climate changes. Pan-American Journal of Aquatic Sciences 5: 52-63

Mandrioli, M., and G. Manicardi. 2013. Evolving aphids: one genome-one organism insects or holobionts. Invertebrate Survival Journal 10:1-6.

McGrath, T., and G. Smith. 1999. Community shifts in the surface mucopolysaccharide layer microbiota of Agaricia sp. during the 1995/6 and 1998/9 bleaching events on patch reefs of San Salvador Island, Bahamas.in 29th meeting of the Association of Marine Laboratories of the Caribbean, Cumana, Venezuela.

Meadow, J. F., A. E. Altrichter, A. C. Bateman, J. Stenson, G. Brown, J. L. Green, and B. J. Bohannan. 2015. Humans differ in their personal microbial cloud. PeerJ 3:e1258.

Mendonça-Neto, J., and B. A. da Gama. 2009. The native Palythoa caribaeorum overgrows on invasive species in the intertidal zone. Coral Reefs 28:497-497.

Meyer, F., D. Paarmann, M. D'Souza, R. Olson, E. M. Glass, M. Kubal, T. Paczian, A. Rodriguez, R. Stevens, A. Wilke, J. Wilkening, and R. A. Edwards. 2008. The metagenomics RAST server - a public resource for the automatic phylogenetic and functional analysis of metagenomes. Bmc Bioinformatics 9:386.

Minard, G., P. Mavingui, and C. V. Moro. 2013. Diversity and function of bacterial microbiota in the mosquito holobiont. Parasites \& vectors 6:1.

Moore, R. E., and P. J. Scheuer. 1971. Palytoxin: A new marine toxin from a coelenterate. Science 172:495-498.

Morrow, K. M., A. G. Moss, N. E. Chadwick, and M. R. Liles. 2012. Bacterial associates of two Caribbean coral species reveal species-specific distribution and geographic variability. Applied and Environmental Microbiology 78:6438-6449.

Nelson, C. E., S. J. Goldberg, L. Wegley Kelly, A. F. Haas, J. E. Smith, F. Rohwer, and C. A. Carlson. 2013. Coral and macroalgal exudates vary in neutral sugar composition and differentially enrich reef bacterioplankton lineages. The ISME Journal 7:962-979.

Oigman-pszczol, S. S., and J. C. Creed. 2004. Size structure and spatial distribution of the Scleractinia at Armacao Dos Buzios, Brazil. Marine Ecology 74:433-448.

Olsén, A., A. Jonsson, and S. Normark. 1989. Fibronectin binding mediated by a novel class of surface organelles on Escherichia coli. Nature 338:652-5.

Overbeek, R., T. Begley, R. M. Butler, J. V. Choudhuri, H.-Y. Chuang, M. Cohoon, V. de Crécy-Lagard, N. Diaz, T. Disz, and R. A. Edwards. 2005. The subsystems approach to genome annotation and its use in the project to annotate 1000 genomes. Nucleic Acids Research 33:5691-5702.

Parks, D. H., and R. G. Beiko. 2010. Identifying biologically relevant differences between metagenomic communities. Bioinformatics 26:715-721.

Pellegrini, O., N. Mathy, A. Gogos, L. Shapiro, and C. Condon. 2005. The Bacillus subtilis ydcDE operon encodes an endoribonuclease of the MazF/PemK family and its inhibitor. Molecular Microbiology 56:1139-1148.

Ritchie, K. B. 2006. Regulation of microbial populations by coral surface mucus and mucus-associated bacteria. Marine Ecology Progress Series 322:1-14.

Ritchie, K. B., J. Dennis, T. McGrath, and G. W. Smith. 1994. Bacteria associated with bleached and nonbleached areas of Montastrea annularis. Pages 75-80 in Proceedings Symposium Natural History Bahamas.

Peer] reviewing PDF | (2016:10:13683:2:2:ACCEPTED 16 Jul 2017) 
560

561

562

563

564

565

566

567

568

569

570

571

572

573

574

575

576

577

578

579

580

581

582

583

584

585

586

587

588

589

590

591

592

593

594

595

596

597

598

599

600

601

602

603

604

605

606

607

608

609

610
Roberts, C. M., and V. C. P. Nicholas. 1993. Marine reserves: Simple solutions to managing complex fisheries? Ambio 22:363-368.

Rohwer, F., V. Seguritan , F. Azam , N. Knowlton 2002 Diversity and distribution of coral-associated bacteria. Marine Ecology Progress Series 243: 1-10.

Rosenberg, E., and L. Falkovitz. 2004. The Vibrio shiloi/Oculina patagonica Model System of Coral Bleaching. Annual Review of Microbiology 58:143-159.

Sandkvist, M. 2001. Type II secretion and pathogenesis. Infection and Immunity 69:3523-3535.

Schmieder, R., and R. Edwards. 2011. Quality control and preprocessing of metagenomic datasets. Bioinformatics 27:863-864.

Seemann, P., C. Gernert, S. Schmitt, D. Mebs, and U. Hentschel. 2009. Detection of hemolytic bacteria from Palythoa caribaeorum (Cnidaria, Zoantharia) using a novel palytoxin-screening assay. Antonie Van Leeuwenhoek International Journal of General and Molecular Microbiology 96:405411.

Seymour, J. R., N. Patten, D. G. Bourne, and J. G. Mitchell. 2005. Spatial dynamics of virus-like particles and heterotrophic bacteria within a shallow coral reef system. Marine Ecology Progress Series 288: $1-8$.

Shashar, N., S. Kinane, P. Jokiel, and M. Patterson. 1996. Hydromechanical boundary layers over a coral reef. Journal of Experimental Marine Biology and Ecology 199:17-28.

Silveira, C. B., A. W. Silva-Lima, R. B. Francini-Filho, J. S. Marques, M. G. Almeida, C. C. Thompson, C. E. Rezende, R. Paranhos, R. L. Moura, and P. S. Salomon. 2015. Microbial and sponge loops modify fish production in phase-shifting coral reefs. Environmental Microbiology 17:3832-3846.

Smith, J. E., M. Shaw, R. a. Edwards, D. Obura, O. Pantos, E. Sala, S. A. Sandin, S. Smriga, M. Hatay, and F. L. Rohwer. 2006. Indirect effects of algae on coral: algae-mediated, microbe-induced coral mortality. Ecology Letters 9:835-845.

Suchanek, T. H., and D. J. Green. 1981. Interspecific competition between Palythoa caribaeorum and other sessile invertebrates on St. Croix reefs, US Virgin Islands. Pages 679-684 in Proceedings of 4th International Coral Reef Symposium.

Sun, W., F. Zhang, L. He, and Z. Li. 2014. Pyrosequencing reveals diverse microbial community associated with the Zoanthid Palythoa australiae from the South China Sea. Microbial Ecology 67:942-950.

Sweet, M. J., J. C. Bythell, and M. M. Nugues. 2013. Algae as reservoirs for coral pathogens. PLoS One 8 (7):e69717

Thauer, R. K. 1998. Biochemistry of methanogenesis: a tribute to Marjory Stephenson: 1998 Marjory Stephenson Prize Lecture. Microbiology 144:2377-2406.

Thurber, R. V., D. Willner-Hall, B. Rodriguez-Mueller, C. Desnues, R. A. Edwards, F. Angly, E. Dinsdale, L. Kelly, and F. Rohwer. 2009. Metagenomic analysis of stressed coral holobionts. Environmental Microbiology 11:2148-2163.

Tout, J., T. C. Jeffries, N. S. Webster, R. Stocker, P. J. Ralph, and J. R. Seymour. 2014. Variability in microbial community composition and function between different niches within a coral reef. Microbial Ecology 67: 540-552.

Vandenkoornhuyse, P., A. Quaiser, M. Duhamel, A. Le Van, and A. Dufresne. 2015. The importance of the microbiome of the plant holobiont. New Phytologist 206:1196-1206.

Wegley, L., R. Edwards, B. Rodriguez-Brito, H. Liu, and F. Rohwer. 2007. Metagenomic analysis of the microbial community associated with the coral Porites astreoides. Environmental Microbiology 9:2707-2719.

Weil, E., G. Smith, and D. L. Gil-agudelo. 2006. Status and progress in coral reef disease research. Disease of Aquatic Organisms 69:1-7.

Wild, C., W. Niggl, M. S. Naumann, and A. F. Haas. 2010. Organic matter release by Red Sea coral reef organisms-potential effects on microbial activity and in situ $\mathrm{O}_{2}$ availability. Marine Ecology Progress Series 411:61-71. 
611

PeerJ reviewing PDF | (2016:10:13683:2:2:ACCEPTED 16 Jul 2017) 


\section{Figure 1}

Percent cover of benthic organisms.

Multiple photographs were taken to accurately describe percent cover of macro-organism within each quadrat. A) Points were selected on a $1 \mathrm{~m} \times 1 \mathrm{~m}$ quadrat. A representative photograph of each macro-organism tested including, B) M. braziliensis, C) Fleshy macroalgae, D) Turf algae, E) P. caribaeorum, and F) Water Column sampling.

\section{A}

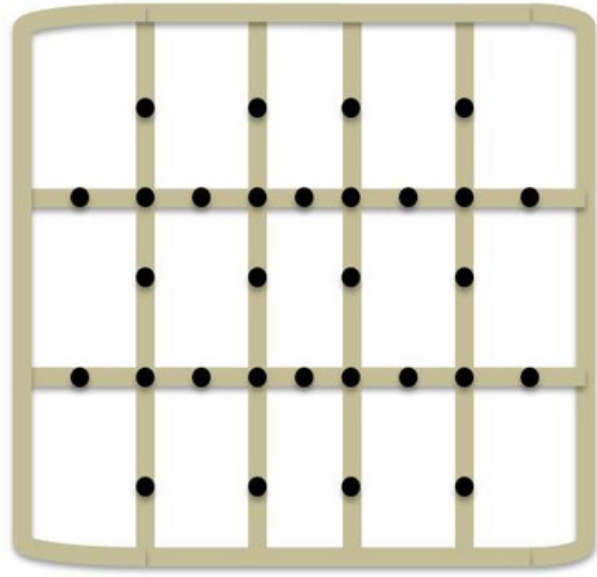

D

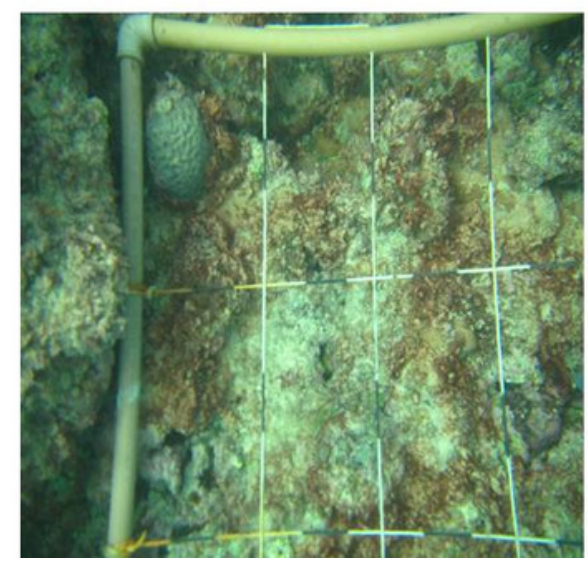

B

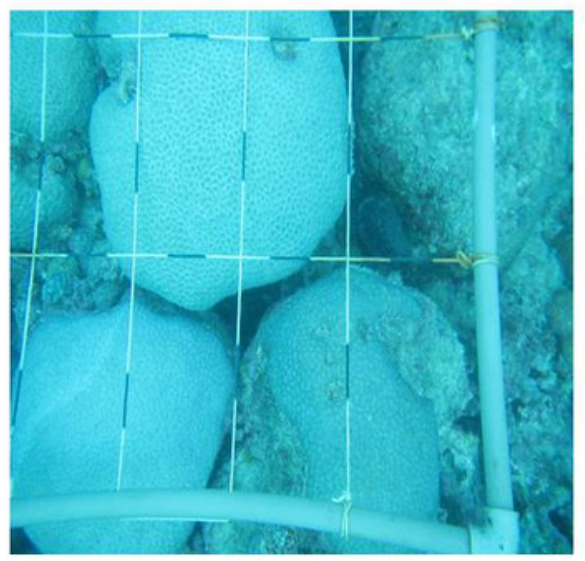

$E$

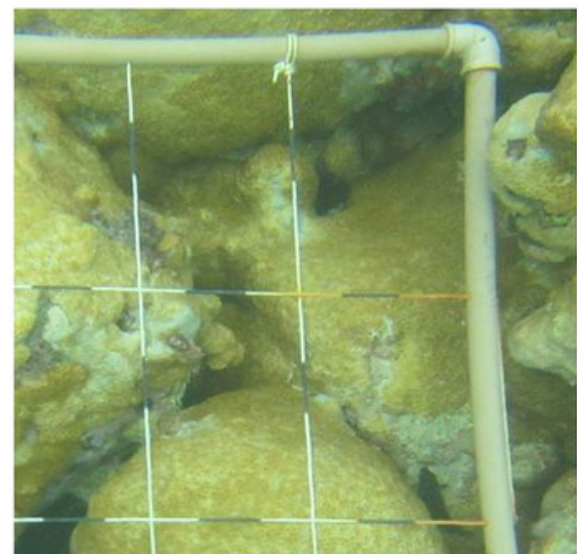

C

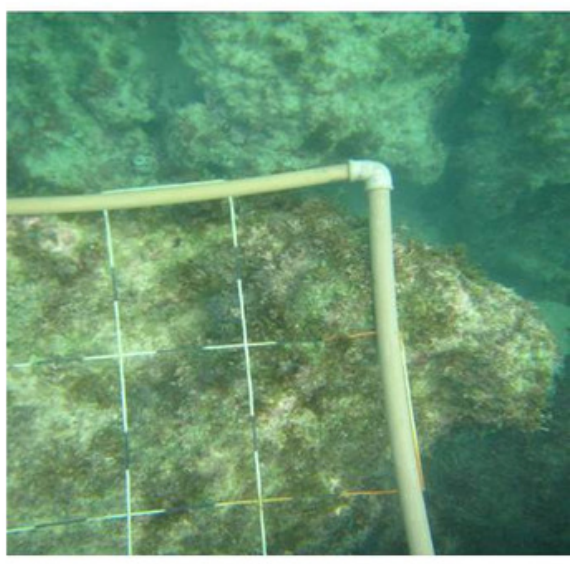

F

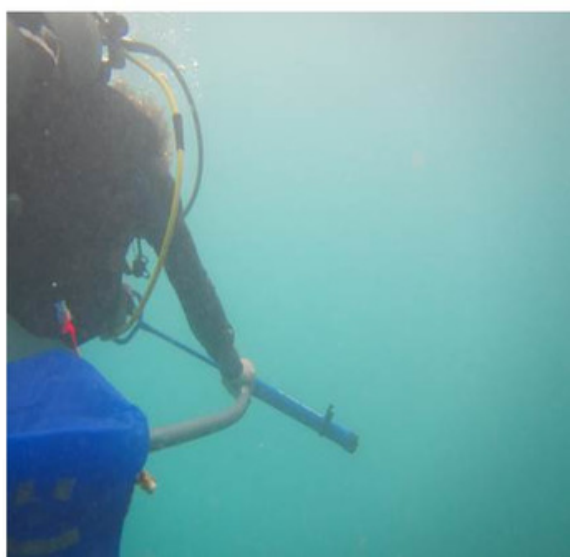


Figure 2

The 20 most abundant genera across the five samples.

An asterisk above each genera shows significance differences, while color delineates which samples varied.

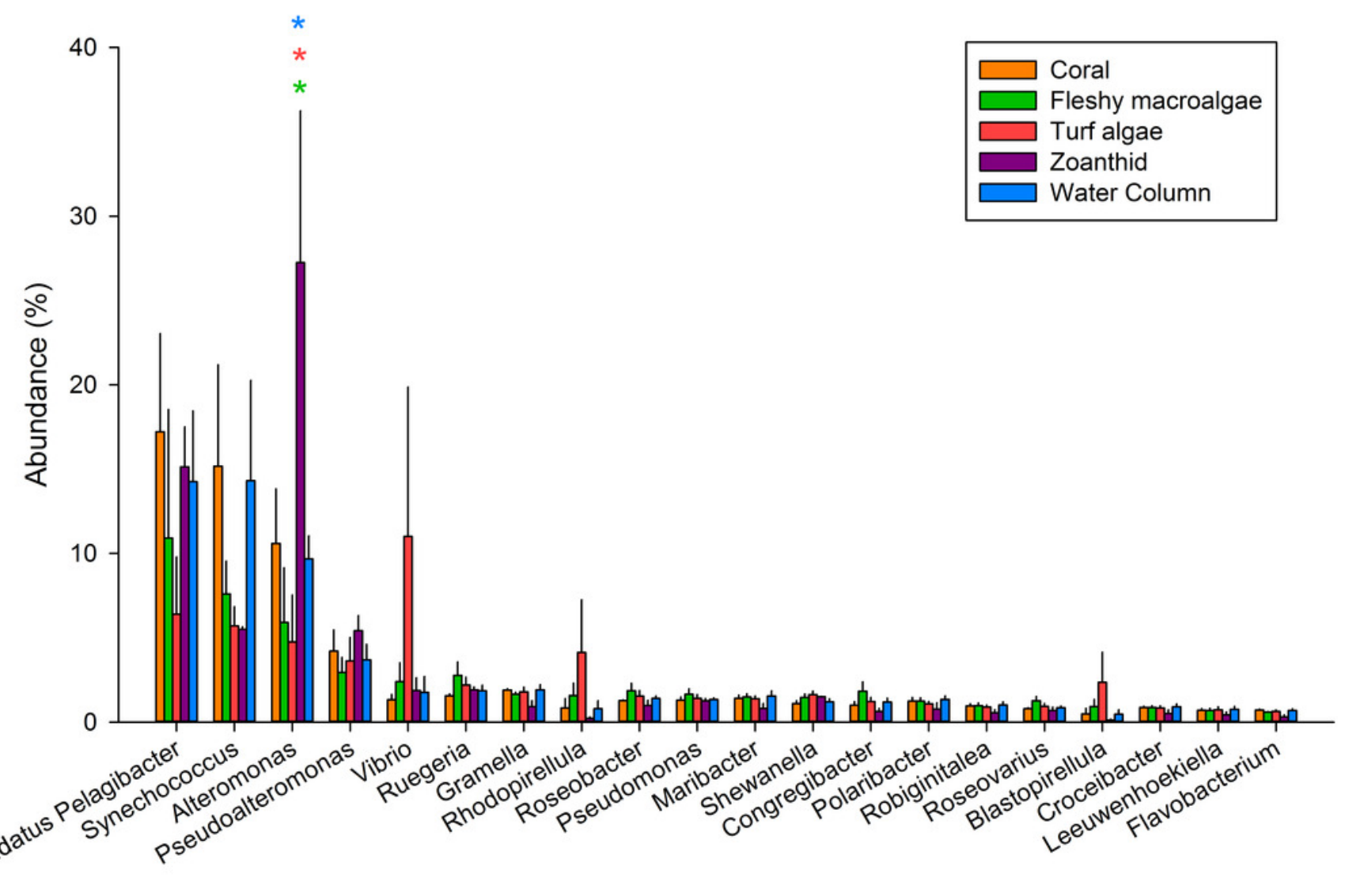

Genera 
Figure 3

Canonical Discriminant Analysis based on taxa.

A CDA was run using the genus level of the aura-biomes or microbial communities to determine which genera drove differences between groups. 


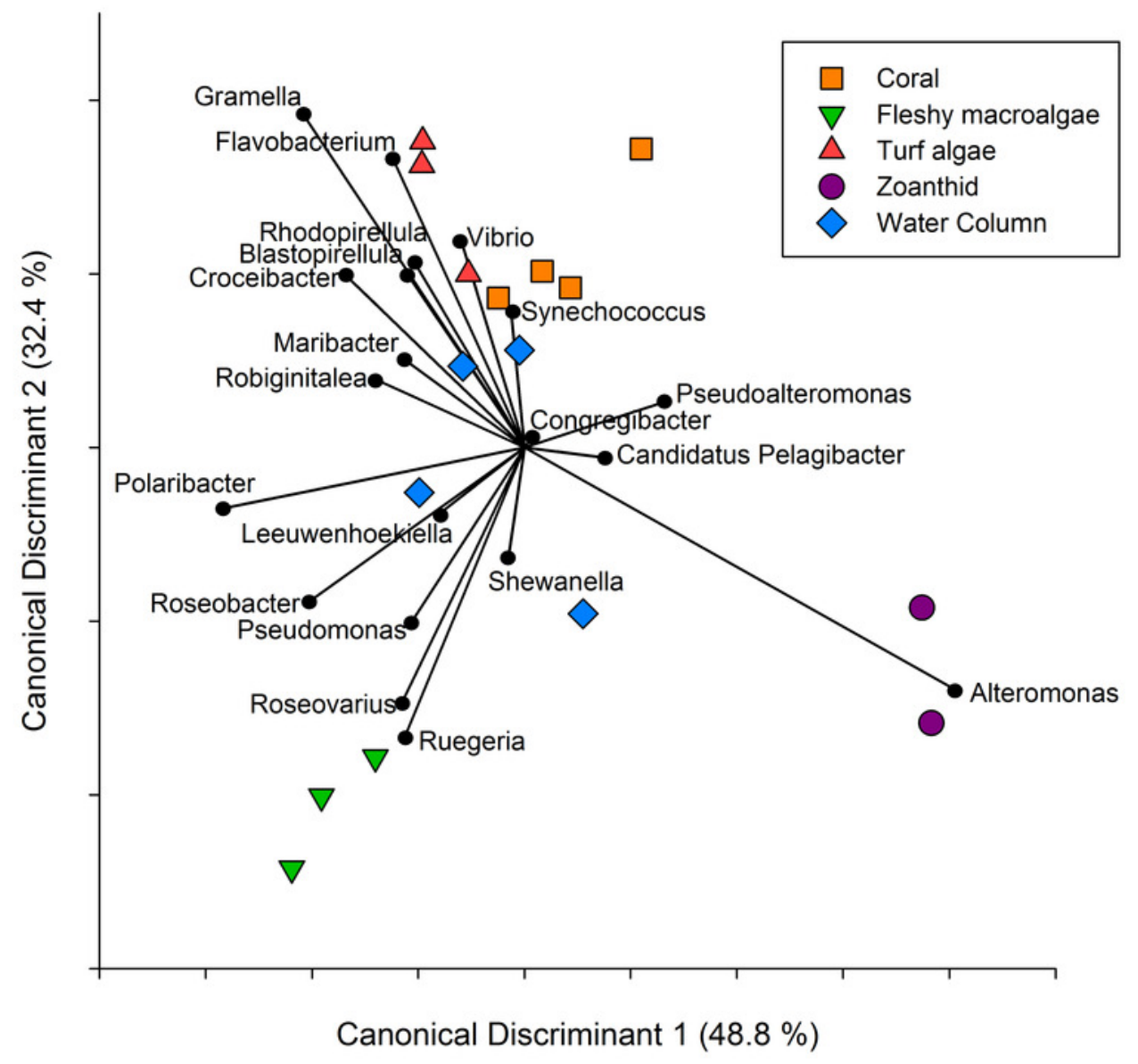




\section{Figure 4}

Metabolic pathways at the most broad level.

Pathways were averaged between samples and those that differed significantly between treatments were visualized. Asterisks above each sample signify significance, while color delineates which sample it is greater than.

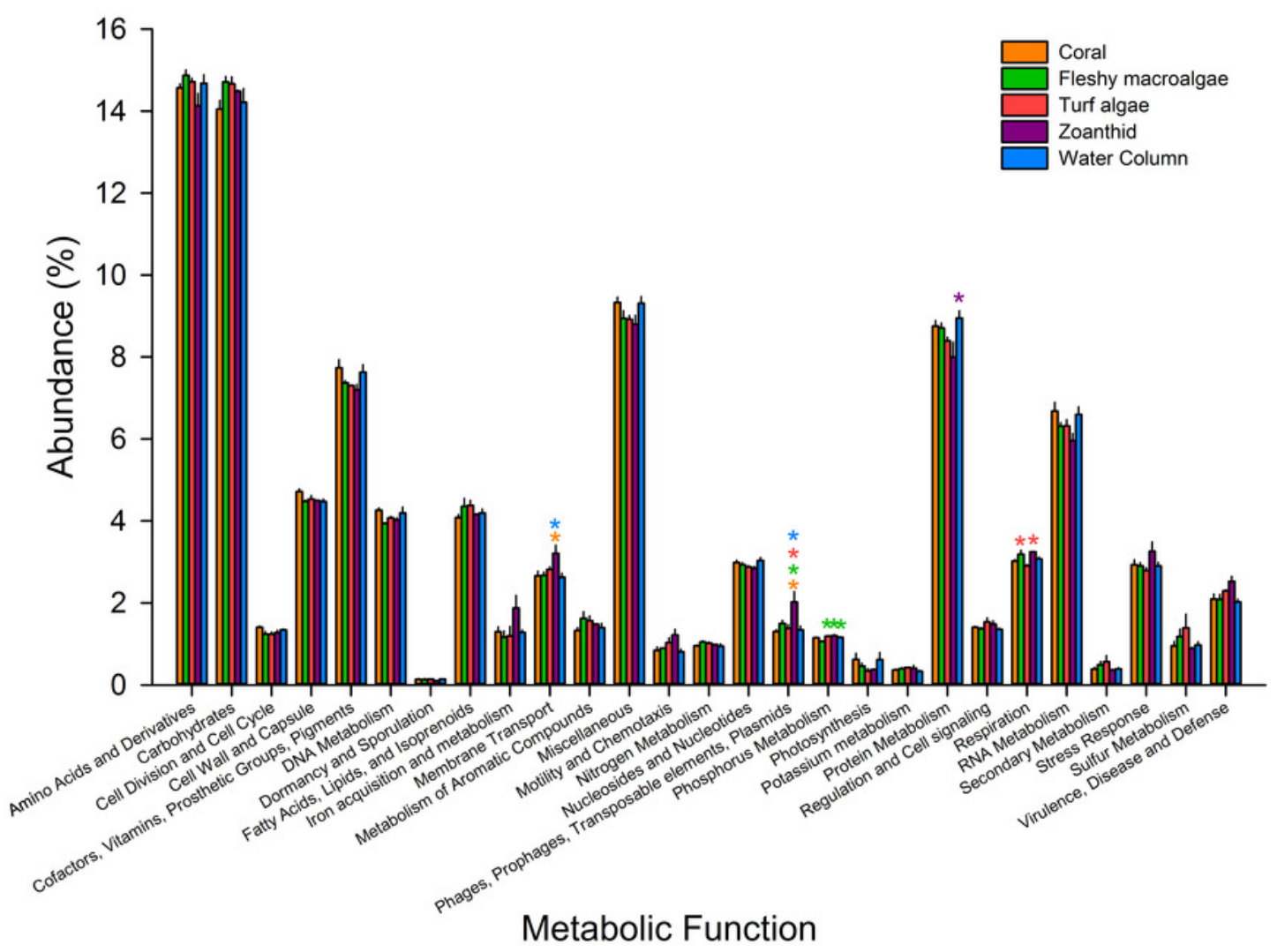


Figure 5

Canonical Discriminant Analysis based on metabolic functions.

The metabolic pathways that drove differences between each of the four macro-organisms and water sample do not overlay multiple samples.

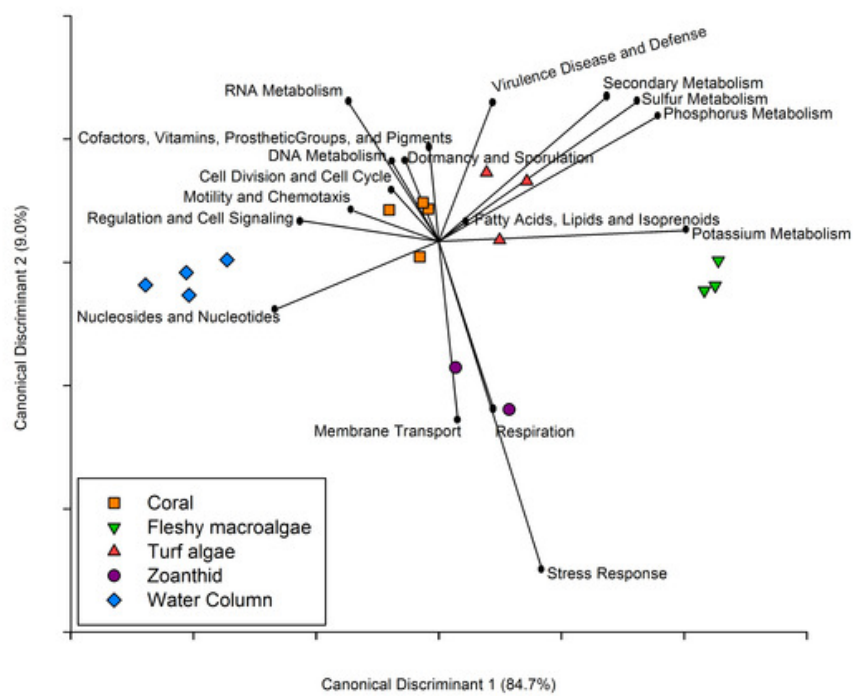




\section{Figure 6}

Interactions between macro-organisms and microbial communities on a reef space.

The exudate from the macro-organism induces and selects for communities whose taxa and metabolic functions create water conditions that are detrimental to neighboring species (both macro and microbial).

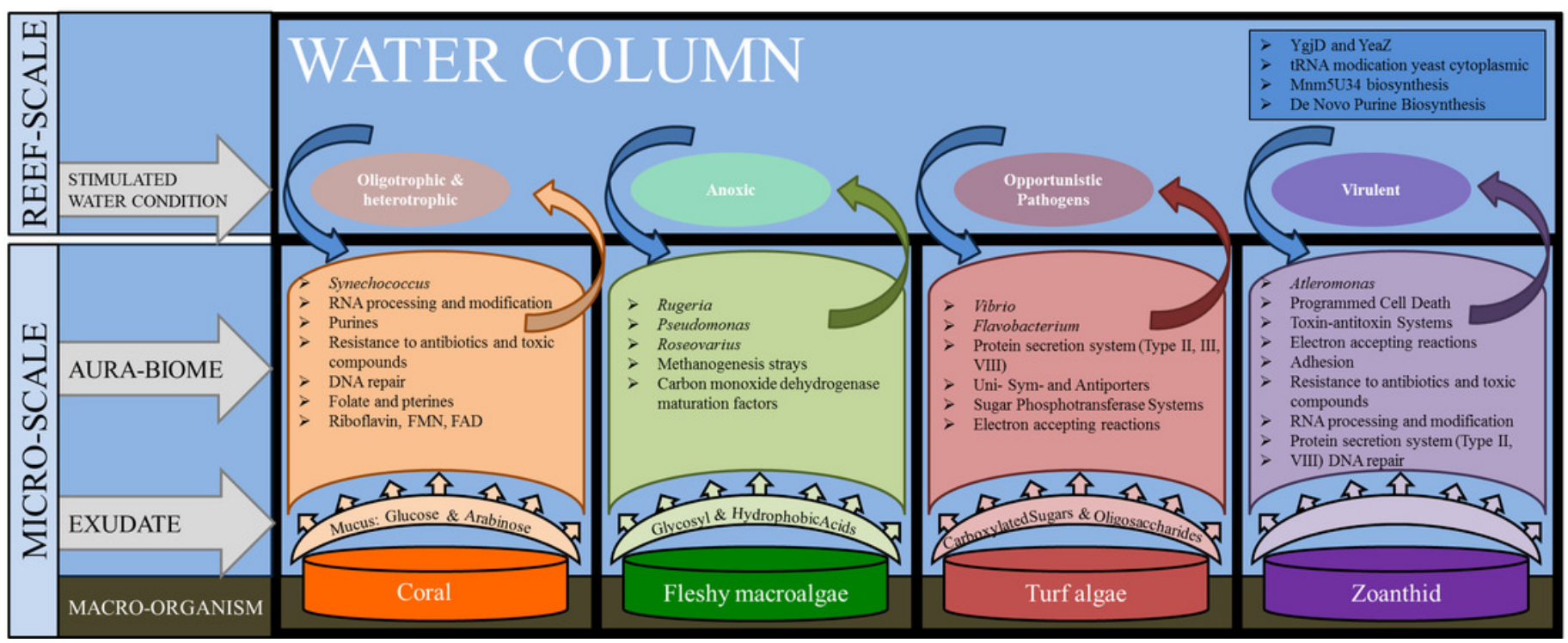




\section{Table $\mathbf{1}$ (on next page)}

Summary of significantly different metabolic processes

These specific metabolisms were significantly upregulated and found within the pathways driving differences between treatments in the metabolism CDA. 
1 Table 1. Summary of significantly different metabolic processes between the treatments.

\begin{tabular}{|c|c|c|c|}
\hline Organism Over Represented & $\begin{array}{c}\text { Broad Metabolic } \\
\text { Processes }\end{array}$ & Gene Pathways & ETA/P Value \\
\hline Zoanthid & $\begin{array}{c}\text { Regulation and Cell } \\
\text { Signaling }\end{array}$ & $\begin{array}{l}\text { Phd-Doc, YdcE- } \\
\text { YdcD toxin- } \\
\text { antitoxin }\end{array}$ & $\begin{array}{l}\eta^{2}=0.662 \\
p=0.012\end{array}$ \\
\hline Zoanthid & $\begin{array}{c}\text { Nucleoside and } \\
\text { Nucleotides }\end{array}$ & Purine Utilization & $\begin{array}{l}\eta^{2}=0.650 \\
p=0.014\end{array}$ \\
\hline Zoanthid & Stress Response & $\begin{array}{c}\text { Bacterial } \\
\text { Hemoglobins }\end{array}$ & $\begin{array}{l}\eta^{2}=0.621 \\
p=0.021\end{array}$ \\
\hline Zoanthid & Stress Response & $\begin{array}{l}\text { Universal Stress } \\
\text { Protein Family }\end{array}$ & $\begin{array}{l}\eta^{2}=0.650 \\
p=0.014\end{array}$ \\
\hline Zoanthid & Respiration & $\begin{array}{c}\text { Respiratory } \\
\text { dehydrogenases }\end{array}$ & $\begin{array}{l}\eta^{2}=0.682 \\
p=0.008\end{array}$ \\
\hline Zoanthid & Respiration & $\begin{array}{l}\text { Terminal } \\
\text { cytochrome C } \\
\text { oxidases }\end{array}$ & $\begin{array}{l}\eta^{2}=0.553 \\
p=0.048\end{array}$ \\
\hline Zoanthid & $\begin{array}{l}\text { Virulence Disease } \\
\text { and Defense }\end{array}$ & $\begin{array}{l}\text { Adhesions in } \\
\text { staphylococcus }\end{array}$ & $\begin{array}{l}\eta^{2}=0.658 \\
p=0.013\end{array}$ \\
\hline Zoanthid & $\begin{array}{l}\text { Virulence Disease } \\
\text { and Defense }\end{array}$ & Arsenic Resistance & $\begin{array}{l}\eta^{2}=0.559 \\
p=0.045\end{array}$ \\
\hline Zoanthid & $\begin{array}{l}\text { Phosphorus } \\
\text { Metabolism }\end{array}$ & P uptake & $\begin{array}{l}\eta^{2}=0.750 \\
p=0.002\end{array}$ \\
\hline Zoanthid & $\begin{array}{l}\text { Phosphorus } \\
\text { Metabolism }\end{array}$ & $\begin{array}{l}\text { Phosphate-binding } \\
\text { DING proteins }\end{array}$ & $\begin{array}{l}\eta^{2}=0.713 \\
p=0.005\end{array}$ \\
\hline Zoanthid & RNA Metabolism & $\begin{array}{l}\text { Group II intron- } \\
\text { associated genes }\end{array}$ & $\begin{array}{l}\eta^{2}=0.598 \\
p=0.029\end{array}$ \\
\hline Zoanthid & RNA Metabolism & $\begin{array}{l}\text { Polyadenylation } \\
\text { specificity factors }\end{array}$ & $\begin{array}{l}\eta^{2}=0.697 \\
p=0.006\end{array}$ \\
\hline Zoanthid & RNA Metabolism & $\begin{array}{l}\text { RNA polymerase } \\
\text { III initiation factor }\end{array}$ & $\begin{array}{l}\eta^{2}=0.562 \\
p=0.044\end{array}$ \\
\hline Zoanthid & $\begin{array}{l}\text { DNA Metabolism } \\
\text { pathways }\end{array}$ & $\begin{array}{l}\text { 2-phosphoglycolate } \\
\text { salvage }\end{array}$ & $\begin{array}{l}\eta^{2}=0.670 \\
p=0.011\end{array}$ \\
\hline Turf algae & Membrane Transport & $\begin{array}{c}\text { Fap Amyloid Fiber } \\
\text { Secretion }\end{array}$ & $\begin{array}{l}\eta^{2}=0.606 \\
p<0.001\end{array}$ \\
\hline Turf algae & Membrane Transport & General Secretion & $\begin{array}{l}\eta^{2}=0.667 \\
p=0.011\end{array}$ \\
\hline Turf algae & Membrane Transport & $\begin{array}{c}\text { NhaA, NhaD and } \\
\text { Sodium-dependent } \\
\text { phosphate } \\
\text { transporters }\end{array}$ & $\begin{array}{l}\eta^{2}=0.605 \\
p=0.026\end{array}$ \\
\hline Turf algae & Membrane Transport & $\begin{array}{c}\text { Fructose and } \\
\text { Mannose Inducible } \\
\text { PTS }\end{array}$ & $\begin{array}{l}\eta^{2}=0.578 \\
p=0.036\end{array}$ \\
\hline
\end{tabular}




\begin{tabular}{|c|c|c|c|c|}
\hline \multicolumn{2}{|c|}{ Turf algae } & Membrane Transport & $\begin{array}{c}\text { Galactose-inducible } \\
\text { PTS }\end{array}$ & $\begin{array}{l}\eta^{2}=0.623 \\
p=0.021\end{array}$ \\
\hline \multicolumn{2}{|c|}{ Turf algae } & Membrane Transport & $\begin{array}{c}\text { Sucrose-specific } \\
\text { PTS }\end{array}$ & $\begin{array}{l}\eta^{2}=0.611 \\
p=0.024\end{array}$ \\
\hline \multicolumn{2}{|c|}{ Turf algae } & Membrane Transport & $\begin{array}{l}\text { Phosphoglycerate } \\
\text { transport }\end{array}$ & $\begin{array}{l}\eta^{2}=0.835 \\
p<0.001\end{array}$ \\
\hline \multicolumn{2}{|c|}{ Turf algae } & Membrane Transport & Type III Secretion & $\begin{array}{l}\eta^{2}=0.628 \\
p=0.019\end{array}$ \\
\hline \multicolumn{2}{|c|}{ Turf algae } & $\begin{array}{l}\text { Nucleoside and } \\
\text { Nucleotides }\end{array}$ & $\begin{array}{l}\text { Pyrimidine } \\
\text { conversions }\end{array}$ & $\begin{array}{l}\eta^{2}=0.559 \\
p=0.045\end{array}$ \\
\hline \multicolumn{2}{|c|}{ Turf algae } & Respiration & $\begin{array}{l}\text { Tetrathionate } \\
\text { respiration }\end{array}$ & $\begin{array}{l}\eta^{2}=0.635 \\
p=0.018\end{array}$ \\
\hline Turf algae & $\begin{array}{c}\text { Fleshy } \\
\text { macroalgae }\end{array}$ & Respiration & $\begin{array}{c}\text { Methanogenesis } \\
\text { strays }\end{array}$ & $\begin{array}{l}\eta^{2}=0.800 \\
p=0.026\end{array}$ \\
\hline \multicolumn{2}{|c|}{ Fleshy macroalgae } & Respiration & $\begin{array}{l}\text { Carbon monoxide } \\
\text { dehydrogenase } \\
\text { maturation factors }\end{array}$ & $\begin{array}{l}\eta^{2}=0.557 \\
p=0.046\end{array}$ \\
\hline \multicolumn{2}{|c|}{ Water Column } & $\begin{array}{l}\text { Cell Division and } \\
\text { Cell Cycle }\end{array}$ & YgjD and YeaZ & $\begin{array}{l}\eta^{2}=0.702 \\
p=0.006\end{array}$ \\
\hline \multicolumn{2}{|c|}{ Water Column } & RNA Metabolism & tRNA modification & $\begin{array}{l}\eta^{2}=0.582 \\
p=0.035\end{array}$ \\
\hline Coral & Water Column & RNA Metabolism & $\begin{array}{l}\text { Mnm5U34 } \\
\text { biosynthesis }\end{array}$ & $\begin{array}{l}\eta^{2}=0.566 \\
p=0.041\end{array}$ \\
\hline Coral & Water Column & $\begin{array}{l}\text { Nucleoside and } \\
\text { Nucleotides }\end{array}$ & $\begin{array}{l}\text { De Novo Purine } \\
\text { Biosynthesis }\end{array}$ & $\begin{array}{l}\eta^{2}=0.648 \\
p=0.015\end{array}$ \\
\hline & & $\begin{array}{l}\text { Virulence Disease } \\
\text { and Defense }\end{array}$ & $\begin{array}{l}\text { Methicillin } \\
\text { resistance }\end{array}$ & $\begin{array}{l}\eta^{2}=0.635 \\
p=0.017\end{array}$ \\
\hline & & $\begin{array}{c}\text { DNA Metabolism } \\
\text { pathways }\end{array}$ & $\begin{array}{l}\text { DNA Repair Base } \\
\text { Excision }\end{array}$ & $\begin{array}{l}\eta^{2}=0.589 \\
p=0.032\end{array}$ \\
\hline & & $\begin{array}{l}\text { Cofactors, Vitamins, } \\
\text { Prosthetic Groups, } \\
\text { and Pigments }\end{array}$ & $\begin{array}{c}\text { Pterin Metabolism } \\
3\end{array}$ & $\begin{array}{l}\eta^{2}=0.626 \\
p=0.020\end{array}$ \\
\hline & & $\begin{array}{c}\text { Vitamins, Prosthetic } \\
\text { Groups, and } \\
\text { Pigments }\end{array}$ & Riboflavin to FAD & $\begin{array}{l}\eta^{2}=0.587 \\
p=0.033\end{array}$ \\
\hline & & $\begin{array}{c}\text { Vitamins, Prosthetic } \\
\text { Groups, and } \\
\text { Pigments }\end{array}$ & YgfZ & $\begin{array}{l}\eta^{2}=0.638 \\
p=0.017\end{array}$ \\
\hline
\end{tabular}

